\title{
Analysis Influence of Organizational Commitment, Job Satisfaction, and Work Stress on Turnover Intention of Outsourching Employee in Automotive Company at PT. XYZ
}

\author{
Anisah Ulfah Fauziyya ${ }^{1}$, Erry Rimawan ${ }^{2}$, Tubagus Hendri Febriana ${ }^{3}$, Febri Winday ${ }^{4}$ \\ Department of Industrial Engineering ${ }^{1,2,3}$, Department of Magister Management ${ }^{4}$ \\ Mercu Buana University, Jakarta, Indonesia
}

\begin{abstract}
In an organization the role of human resources is a very important determining factor for the effectiveness and success of an organization in achieving its goals. But in reality, there are still many companies that use outsourching services. With the rise of the practice of outsourcing so far it is recognized to be more detrimental to workers because employment relations are always in the form of non-permanent or contractual contracts (fixed time contracts), lower wages, limited social security, lack of job security, and lack of career development guarantees. These factors make high turnover intention in PT XYZ. From every outsourching employee's complaints and based on data to the company, the authors indicate doubts about organizational commitment, job satisfaction, and work stress. The author uses questionnaires and interviews as a data collection tool and takes a sampling of the outsourching employee population. Then analyzed using the smartPLS application. The results showed that organizational commitment had a negative and significant effect on turnover intention, job satisfaction had a negative and significant effect on turnover intention and work stress had a positive and significant effect on the turnover intention of outsourcing employee in PT XYZ.
\end{abstract}

Keywords:- Organizational Commitment, Job Satisfaction, Work Stress, Turnover Intention.

\section{INTRODUCTION}

An organization is formed to achieve a set goal. In the process of achieving these goals, it takes human resources who are ready to carry out the task and concentrate fully devoting all the attention of energy and thoughts to advance the organization. For this reason, a structural change in business management is needed by reducing the range of management control, by cutting in such a way that it can be more effective, efficient, and productive. In this connection it can be understood that the tendency of companies to hand over part of the work carried out to other companies, one part or several parts of the company's activities to other companies through work contracting agreements or agreements of workers or outsourcing service providers.
With the rise of the practice of outsourcing so far it is recognized to be more detrimental to workers because employment relations are always in the form of nonpermanent or contractual contracts (fixed time contracts), lower wages, limited social security, lack of job security, and lack of career development guarantees.

Violations that often occur are low work protection and conditions of work for workers. The protection and terms of employment provided by employers to workers are generally below the applicable standards where outsourcing workers are employed. Even though the realization of the employment relationship is made in writing between the outsourcing company and the worker, the recruitment service company benefits by deducting part of the rights received by the worker from the company where the worker is placed.

Because of the following problem, author found the data from HRD Departement as of below:

\begin{tabular}{|c|c|c|c|c|r}
\hline No & Tahun & $\begin{array}{c}\text { Jumlah } \\
\text { karyawan awal } \\
\text { tahun(Orang) }\end{array}$ & $\begin{array}{c}\text { Jumlah } \\
\text { karyawan yang } \\
\text { keluar(Orang) }\end{array}$ & $\begin{array}{c}\text { Jumlah } \\
\text { karyawan yang } \\
\text { masuk (Orang) }\end{array}$ & $\begin{array}{r}\text { Jumlah kє } \\
\text { akhir t } \\
\text { (Oral }\end{array}$ \\
\hline 1 & 2015 & 94 & 2 & 5 & 97 \\
\hline 2 & 2016 & 97 & 6 & 3 & 94 \\
\hline 3 & 2017 & 94 & 8 & 7 & 93 \\
\hline 4 & 2018 & 93 & 9 & 7 & 91 \\
\hline 5 & 2019 & 91 & 7 & 1 & 85 \\
\hline
\end{tabular}

Fig 1:- Turnover Intention Data

From the following figure, it can be seen that the outsourcing employee turnover rate is quite high for five years from 2015 to 2019 . The intended employees include 64 support staff, 1 receptionist, and 20 drivers.

From the figure above indicates there is relation between organizational commitment, job satisfaction, work stress as an outsourced employee at PT XYZ which is enough to affect turnover intention. Therefore, the authors would like to find out more by conducting a study entitled "Analysis Influence of Organizational Commitment, Job Satisfaction, Work Stress on Turnover Intention of Outsourcing Employees in Automotive Companies at PT.XYZ". 
The problems raised by researchers in this study are:

Does the organizational commitment affect the turnover intention of outsourcing employees at PT XYZ?

$>$ Does the job satisfaction affect the turnover intention of outsourcing employees at PT XYZ?

$>$ Does the stress work affect the turnover intention of outsourcing employees at PT XYZ?

\section{LITERATURE REVIEW}

\section{A. Turnover Intention}

According to Harnoto (2002: 2) turnover intention is marked by various matters concerning employee behavior. These indications can be used as a reference to predict employee turnover intention in a company. Among others are Increased attendance, getting lazy at work, increasing the violation of work rules, increased protests against superiors, and positive behavior that is very different from usual.

Meanwhile, according to Robbins (2001), the factors that affect turnover are grouped into three parts, namely:

1. Organizational-level characteristics, consisting of five parts, namely: organizational structure, job desagn, work stress, reward \& retirement plans, and performance evaluation system.

2. Group level characteristics, consisting of two parts, namely demographic groups and cohesiveness groups.

3. Individual-level characteristics consist of five parts namely age, years of service, material status, job satisfaction and personality-job fit.

\section{B. Organizational Commitment}

Organizational Comitment according to Mobley in Andini (2006: 21) is defined as the level of frequency of identification and the level of individual attachment to a particular organization that is reflected by the characteristics: there is a strong belief and acceptance of organizational values and goals and there is a definite desire to maintain participation in the organization.

Organizational commitment is the degree in which employees identify with the organization and want to continue to actively participate in the organization and want to continue to actively participate in the organization (Newstrorm \& Davis, 1995). Organizational commitment is an attitude of interest shown by employees to the organization as a whole. (Hulin, 1998). Based on these two opinions have the same meaning that employees want to remain in the organization.

Organizational commitment has dimensions as stated by Mowday cited by Sopiah (2008): Affective Commitment, Continuance commitment, and Normative Commitment.

\section{Job Satisfaction}

Job satisfaction is basically something that is individual. Each individual has a different level of satisfaction in accordance with the value system that applies to him. The higher the assessment of the activity felt in accordance with individual desires, the higher the satisfaction with the activity. Thus satisfaction describes one's feelings towards happy or unhappy, satisfied or unsatisfied attitudes at work (Veithzal and Jauvani, 2009). Based on a number of definitions forward by these figures, it can be concluded that job satisfaction is a feeling experienced by someone of the situation and conditions experienced in the work environment in the workplace that creates a feeling of pleasure or discomfort and satisfaction or dissatisfaction with the work performed.

\section{Work Stress}

Stress as a term that summarizes pressure, burden, conflict, fatigue, tension, panic, feelings of rumbling, moodiness and loss of power. Job stress is a condition of tension, which creates physical and psychological imbalances, which affect emotions, thought processes, and employee conditions. People who experience stress can become nervous and feel chronic anxiety, they are often angry and aggressive, unable to relax, or show uncooperative attitudes (Veithzal \& Jauvani, 2009). Stress is a condition that presses oneself and one's soul beyond its limits, so that if it continues to be left without a solution, then this will have an impact on his health. The causes of the onset of stress are (Hasibuan, 2014):

$>$ Difficult and excessive workload

$>$ The pressure and attitude of the leadership is not fair and reasonable

$>$ Unreasonable work time and equipment

$>$ Conflicts between individuals and leaders or work groups

$>$ Reward for services that are too low

$>$ Family matters

\section{METHODOLOGY}

\section{A. Data Collection}

The data collection methods used to obtain data in writing this thesis are: The researcher uses several data collection techniques as follows:

1) Observation Data collection by directly observing the location of research sites.

2) Interview Interview is a data collection technique that is done through face-to-face and question and answer between data collectors and researchers towards the sources or data sources.

3) Questionnaire Questionnaire is a data collection technique that is done through questions posed by relevant resource persons in accordance with the analysis of the requirements needed by the author.

\section{B. Population and Sample}

Respondents of this study are respondents who are works as a outsourching employee at this company. With 80 persons of populations, authors use Slovin formula (Mahi, 2014):

$$
n=\frac{N}{1+N(e)^{n}}
$$

Information:

$\mathrm{N}=$ population size 
$\mathrm{n}=$ Sample size

$\mathrm{e}=$ Margin of error, which is the percentage of inaccuracy due to sampling errors that can still be tolerated by $5 \%$.

With the following formula, then the number of samples will be obtained 70persons.

\section{Data Processing and Analysis Methods}

This study uses explanatory research (explanatory research) aimed at explaining the capacity or relationship between variables Organizational Commitment (X1), Job Satisfaction (X2), Work Stress (X3) and Turnover Intention (Y1), using the PLS (Partial Least Squre) variable.

\section{Outer Model Analysis}

Outer model analysis is carried out to ensure that the measurements used are appropriate to be made measurements (valid and reliable). Analysis of the outer model can be seen from several indicators.

\section{- Test Validity}

$\checkmark$ Using convergent validity. The value of convergent validity is the value of the loading factor on latent variables with the indicators. Expected value $>0.7$

$\checkmark$ Average Variance Extracted (AVE) Expected AVE value> 0.5 .

$\checkmark$ Discriminant validity. This value is a cross loading factor value which is useful for knowing whether the construct has adequate discriminant that is by comparing the loading value of the intended construct must be greater than the value of loading with other constructs

\section{- $\quad$ Test Reliability}

$\checkmark$ Composite Reliability. The data that has composite reliability $>0.7$ has high reliability.

$\checkmark$ Cronbanch Alpha. The reliability test was strengthened with Cronbach Alpha. Expected value> 0.6 for all constructs.

\section{$>$ Inner Model Analysis}

While the inner model analysis / structural analysis model is carried out to ensure that the structural model that is built is robust and accurate. Evaluation of the inner model can be seen from several indicators which include:

- The coefficient of determination (R2) in endogenous constructs. According to Chin (1998), the value of R square is 0.67 (strong), 0.33 (moderate) and 0.19 (weak)

- Predictive Relevance (Q2) or also known as StoneGeisser's. This test is performed to determine the predictive capability. If the values obtained are 0.02 (small), 0.15 (medium) and 0.35 (large). Can only be done for endogenous constructs with reflective indicators.

\section{> Hypothesis Testing}

Hypothesis testing is done by looking at the probability value and $t$ statistics. For probability values, the p-value with an alpha of $5 \%$ is less than 0.05 . The t-table value for alpha $5 \%$ is 1.96 . So, the acceptance / rejection criteria Hypothesis is $\mathrm{Ha}$ is accepted and $\mathrm{HO}$ is rejected when t-statistics> 1.96. To reject / accept the hypothesis using probability, Ha is accepted if the value of $\mathrm{p}<0.05$.

\section{Framework}

This research proccess the data quantitatively, the data obtained in the study will be processed and analyzed so that it can provide a clear work system. The research stages can be seen in Figure 2.

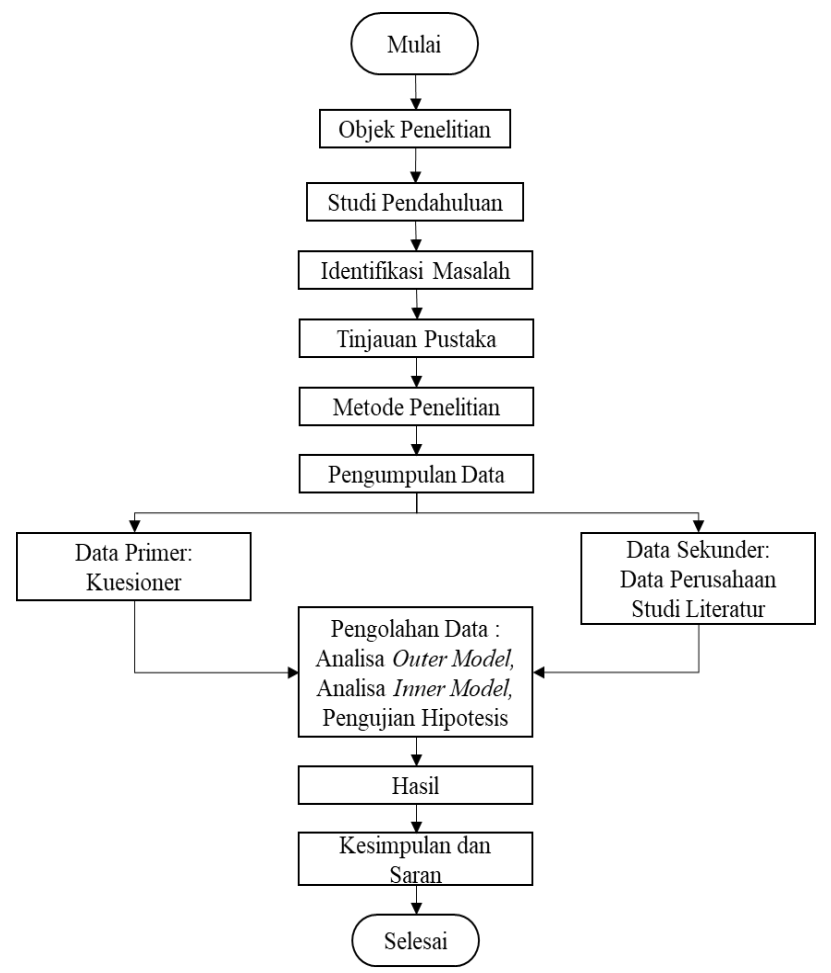

Fig 2:- Framework

\section{RESULTS AND DISCUSSION}

\section{* Characteristics of Respondents}

Based on the results of research on 70 outsourcing employees, the following characteristics of respondents were obtained:

\section{Based on Gender}

\begin{tabular}{|l|l|r|r|}
\hline \multirow{2}{*}{ No } & \multirow{2}{*}{ Jenis Kelamin } & \multicolumn{2}{|c|}{ Jumlah } \\
\cline { 3 - 4 } & & Absolut & \multicolumn{1}{c|}{ Persen } \\
\hline 1 & Laki-laki & 44 & $63 \%$ \\
\hline 2 & Perempuan & 26 & $37 \%$ \\
\hline \multicolumn{2}{|c|}{ Jumlah } & 70 & $100 \%$ \\
\hline
\end{tabular}

Fig 3:- Respondents Based on Gender

It is known that the number of male respondents is 44 people or $63 \%$ and the number of female respondents is 26 people or $37 \%$ of the total number of respondents 70 people. 


\section{Based on Age}

\begin{tabular}{|c|c|r|r|}
\hline \multirow{2}{*}{ No } & \multirow{2}{*}{ Umur } & \multicolumn{2}{|c|}{ Jumlah } \\
\cline { 3 - 4 } & & \multicolumn{1}{|c|}{ Absolut } & \multicolumn{1}{c|}{ Persen } \\
\hline 1 & $18-25$ tahun & 23 & $33 \%$ \\
\hline 2 & $26-33$ tahun & 28 & $40 \%$ \\
\hline 3 & $34-41$ tahun & 17 & $24 \%$ \\
\hline 4 & $>41$ tahun & 2 & $3 \%$ \\
\hline \multicolumn{2}{|c|}{ Jumlah } & 70 & $100 \%$ \\
\hline
\end{tabular}

Fig 4:- Respondents based on Age

It is known that the number of respondents aged 18-25 years is 23 people or $33 \%$, aged $26-33$ years is most dominant with as many as 28 people or $40 \%$, aged $34-41$ years as many as 17 people or $24 \%$, and over of 41 years at least 2 people or $3 \%$ of the total respondents were 70 people.

\section{A. Characteristics of Respondents by Education Level}

\begin{tabular}{|c|l|r|r|}
\hline \multirow{2}{*}{ No } & \multirow{2}{*}{ Tingkat Pendidikan } & \multicolumn{2}{|c|}{ Jumlah } \\
\cline { 3 - 4 } & & 17 & \multicolumn{1}{|c|}{ Persen } \\
\hline 1 & SMA/SMK & 23 & $33 \%$ \\
\hline 2 & Diploma & 30 & $43 \%$ \\
\hline 3 & Sarjana & 70 & $100 \%$ \\
\hline & Jumlah &
\end{tabular}

Fig 5:- Respondent based on Education Level

It is known that the number of respondents who have undergraduate education levels is the most dominant, namely as many as 30 people or $43 \%$, then diploma levels as many as 23 people or $33 \%$ and the least is the high school / vocational level as many as 17 people or $24 \%$ of the total respondents 70 persons.

\section{B. Characteristics of Respondents by Education Level}

\begin{tabular}{|c|c|r|r|}
\hline \multirow{2}{*}{ No } & \multirow{2}{*}{ Masa Kerja } & \multicolumn{2}{|c|}{ Jumlah } \\
\cline { 3 - 4 } & & Absolut & \multicolumn{1}{c|}{ Persen } \\
\hline 1 & $0-1$ Tahun & 20 & $29 \%$ \\
\hline 2 & 1 - 3 Tahun & 37 & $53 \%$ \\
\hline 3 & $>3$ Tahun & 13 & $19 \%$ \\
\hline \multicolumn{2}{|c|}{ Jumlah } & 70 & $100 \%$ \\
\hline
\end{tabular}

Fig 6:- Respondents by Education Level

It is known that the number of respondents who worked under 1 year was 20 people or $29 \%$, who worked between 1 to 3 years as many as 37 people or 53\%, and those over 3 years were 13 people or $19 \%$ of the total respondents were 70 persons.

\section{* Measurement Model}

Outer Model or Measurement Model is an assessment of the reliability and validity of research variables. There are five criteria for the assessment of the outer model, namely: loading factor, AVE, cross loading factor, composite reliability, and Cronbach alpha. The results of the outer model show the results of testing the reliability and validity of each variable.

\section{Validity Testing}

- Convergent Validity

The loading factor value of each indicator variable. Convergent validity value is the value of the loading factor on latent variables with the indicators. Expected value> 0.7. Which means, the indicator is valid because it has a value of more than 0.7 .

\section{- $A V E$}

To meet the requirements of convergent validity, the AVE value must meet the standard $>0.5$. Based on table 4.6, the AVE value is more than 0.5. This shows that all variables in the model meet the criteria.

\section{- Discriminant Validity}

We have to find cross loading factor value. Cross loading factor is useful to assess whether the construct has adequate discriminant validity by comparing the relationship between these indicators with other variables, it is said that the construct has a high discriminant validity.

\begin{tabular}{|l|r|r|r|r|}
\hline Indikator & $\begin{array}{c}\text { X1 } \\
\text { (KOMITMEN } \\
\text { ORGANISASI) }\end{array}$ & $\begin{array}{c}\text { X2 } \\
\text { (KEPUASAN } \\
\text { KERJA) }\end{array}$ & $\begin{array}{c}\text { X3 (STRES } \\
\text { KERJA) }\end{array}$ & $\begin{array}{c}\text { Y1 } \\
\text { (TURNOVER } \\
\text { INTENTION) }\end{array}$ \\
\hline X1.1 & 0.972 & 0.953 & 0.928 & 0.918 \\
\hline X1.2 & 0.960 & 0.952 & 0.942 & 0.939 \\
\hline X1.3 & 0.958 & 0.945 & 0.954 & 0.929 \\
\hline X1.4 & 0.964 & 0.951 & 0.953 & 0.941 \\
\hline X1.5 & 0.959 & 0.952 & 0.936 & 0.928 \\
\hline X1.6 & 0.959 & 0.950 & 0.935 & 0.924 \\
\hline X1.7 & 0.955 & 0.940 & 0.943 & 0.944 \\
\hline X1.8 & 0.968 & 0.957 & 0.934 & 0.919 \\
\hline X2.1 & 0.952 & 0.956 & 0.942 & 0.939 \\
\hline X2.2 & 0.938 & 0.955 & 0.933 & 0.952 \\
\hline X2.3 & 0.966 & 0.968 & 0.929 & 0.915 \\
\hline X2.4 & 0.947 & 0.954 & 0.934 & 0.910 \\
\hline X2.5 & 0.907 & 0.933 & 0.915 & 0.892 \\
\hline X2.6 & 0.955 & 0.956 & 0.946 & 0.931 \\
\hline X2.7 & 0.953 & 0.958 & 0.937 & 0.930 \\
\hline X2.8 & 0.931 & 0.954 & 0.934 & 0.944 \\
\hline X2.9 & 0.907 & 0.936 & 0.927 & 0.934 \\
\hline X2.10 & 0.902 & 0.924 & 0.876 & 0.857 \\
\hline X3.1 & 0.948 & 0.950 & 0.958 & 0.929 \\
\hline X3.2 & 0.932 & 0.930 & 0.954 & 0.921 \\
\hline X3.3 & 0.930 & 0.938 & 0.942 & 0.933 \\
\hline X3.4 & 0.904 & 0.901 & 0.945 & 0.919 \\
\hline X3.5 & 0.908 & 0.935 & 0.946 & 0.941 \\
\hline X3.6 & 0.944 & 0.946 & 0.954 & 0.898 \\
\hline X3.7 & 0.952 & 0.952 & 0.959 & 0.931 \\
\hline X3.8 & 0.927 & 0.927 & 0.965 & 0.928 \\
\hline Y.1 & 0.928 & 0.950 & 0.937 & 0.973 \\
\hline Y.2 & 0.949 & 0.944 & 0.954 & 0.959 \\
\hline Y.3 & 0.942 & 0.951 & 0.960 & 0.963 \\
\hline Y.4 & 0.924 & 0.926 & 0.966 \\
\hline
\end{tabular}

Fig 7:- Cross Loading Factor

Based on the test, we can know that the value of each indicator against its own variable is greater than the other variables. For example the indicator X1.1 against variable $\mathrm{X} 1$ has a cross loading value of 0.972 . This value is higher when compared with other variables. 
ISSN No:-2456-2165

\section{Reliability Testing}

Reliability testing is performed to determine whether the answers given by respondents can be trusted or reliable using reliability analysis through the Croanbarch alpha method, where an instrument is said to be reliable if it has a reliability coefficient or alpha of 0.05 or more. ccording to Sugiyono (2004) the formula for the reliability coefficient of Croanbarch alpha is:

$$
r i=\frac{k\left\{1-\sum s i\right\}^{2}}{(k-1) s t^{2}}
$$

This technique or formula can be used to determine whether a research instrument is reliable or not. With the criteria of a research instrument said to be reliable using this technique, if the coefficient is reliable $(\mathrm{r} 11)>0.6$. Reliability test is used to use the extent to which the measurement results are relatively consistent if the measurements are repeated twice or more.

\section{- Composite Reliability}

Testing reliability can be shown by the value of composite reliability. Research variables are considered reliable if they have composite reliability values above or> 0.70 (Nunnaly, 1996). All latent variables in this study can be considered to have good reliability because they have composite reliability values above $>0.70$. Here is a graph of composite reliability.

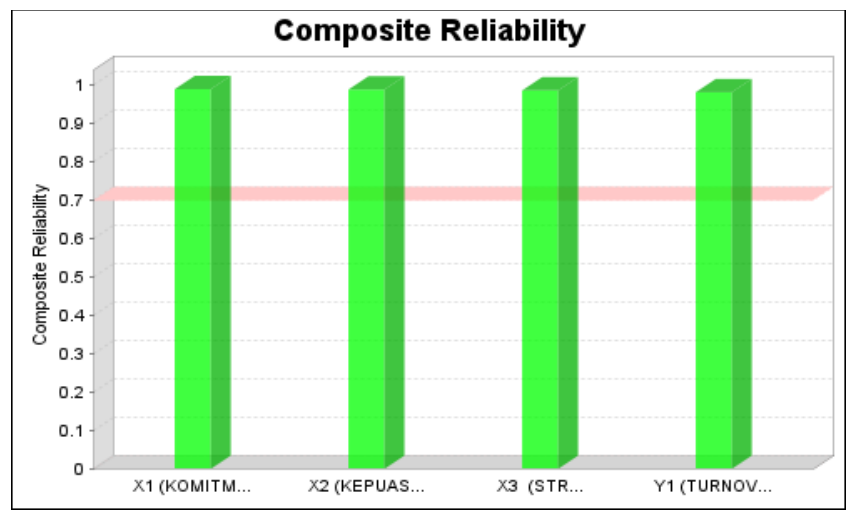

Fig 8:- Diagram Composite Reliability

From the diagram in Figure 8 we can clearly see the composite reliability value is above the standard that is 0.7 .

\section{- Cronbach Alpha}

In addition to composite reliability, the Cronbach alpha value is also a requirement in research to state whether the variables in the study are reliable or not.

\begin{tabular}{|c|c|c|c|c|}
\hline & $\begin{array}{c}\text { Cronbach's } \\
\text { Alpha }\end{array}$ & rho_A & $\begin{array}{c}\text { Composite } \\
\text { Reliability }\end{array}$ & $\begin{array}{c}\text { Average } \\
\text { Variance } \\
\text { Extracted (AVE) }\end{array}$ \\
\hline $\begin{array}{c}\text { Komitmen } \\
\text { Organisasi (X1) }\end{array}$ & $\mathbf{0 . 9 8 6}$ & 0.988 & 0.99 & 0.925 \\
\hline $\begin{array}{c}\text { Kepuasan Kerja } \\
\text { (X2) }\end{array}$ & $\mathbf{0 . 9 6 6}$ & 0.988 & 0.989 & 0.899 \\
\hline Stres Kerja (X3) & $\mathbf{0 . 9 8 4}$ & 0.985 & 0.987 & 0.902 \\
\hline $\begin{array}{c}\text { Turnover } \\
\text { Intention (Y1) }\end{array}$ & $\mathbf{0 . 9 7 6}$ & 0.976 & 0.982 & 0.932 \\
\hline
\end{tabular}

Fig 9:- Corbach Alpha

Based on the Fig above, the Cronbach alpha value of organizational commitment (X1) is 0.986 , job satisfaction (X2) is 0.966 and work stress (X3) is 0.984. All Cronbach alpha values of each variable are above the standard or more than 0.6 , which means that the reliability value of the variable is high.

\section{- Inner Model}

Testing the inner model or structural model is done to see the relationship between variables, significance values and the R-Square of the research model. After knowing the significant relationship between variables, the hypothesis can be concluded. Hypothesis testing is done by bootstrapping resampling method. The test statistic used is the $\mathrm{t}$ test statistic.

\begin{tabular}{|l|c|c|}
\hline \multicolumn{1}{|c|}{ Variabel } & R Square & $\begin{array}{c}\text { R Square } \\
\text { Adjusted }\end{array}$ \\
\hline $\begin{array}{l}\text { Y1 (TURNOVER } \\
\text { INTENTION) }\end{array}$ & 0.921 & 0.904 \\
\hline
\end{tabular}

Fig 10:- R-Square Value

The coefficient of determination (R Square Adjusted) is used to show how much influence the influencing variable has on the affected variable. Based on the table above, the R square adjusted value above 0.904 shows that $90.4 \%$ of the Y variables can be explained by the variables $\mathrm{X} 1, \mathrm{X} 2$, and $\mathrm{X} 3$. While the other $9.6 \%$ is caused by other factors outside the model.

\section{- Path Coefficient}

The value of the path coefficient indicates that testing the variable between the variables is significant and the value is in the range -1 to 1 . To find out which hypothesis is acceptable or not, the t-statistic value must be greater than t table that is 1.96 to reach significant. PLS test results below: 


\begin{tabular}{|l|c|c|l|}
\hline \multicolumn{1}{|c|}{ Hubungan Antar Variabel } & $\begin{array}{c}\text { Koefisien } \\
\text { Jalur }\end{array}$ & $\begin{array}{c}\text { T Statistics } \\
(\mid \mathrm{O} / \mathrm{STDE} \\
\mathrm{V} \mid)\end{array}$ & Keterangan \\
\hline $\begin{array}{l}\text { X1 (KOMITMEN } \\
\text { ORGANISASI) -> Y1 } \\
\text { (TURNOVER INTENTION) }\end{array}$ & -0.106 & 2.694 & Signifikan \\
\hline $\begin{array}{l}\text { X2 (KEPUASAN KERJA) -> } \\
\text { Y1 (TURNOVER } \\
\text { INTENTION) }\end{array}$ & -0.51 & 2.563 & Signifikan \\
\hline $\begin{array}{l}\text { X3 (STRES KERJA) -> Y1 } \\
\text { (TURNOVER INTENTION) }\end{array}$ & 0.58 & 5.756 & Signifikan \\
\hline
\end{tabular}

Fig 11:- Path Coefficient Result in PLS

Based on following figure 11,

The first hypothesis shows the path coefficient value 0.106 and t-statistic value 2.694 on the effect of organizational commitment on turnover intention. The tstatistic value is greater than the t-table value of 1.960 which shows that there is a significant influence between the variables of organizational commitment to turnover intention. Organizational commitment gives a negative influence on the intention to exit as indicated by the path coefficient, which means that the higher the organizational commitment the intention to leave will decrease, so that hypothesis 1 can be accepted.

In the second hypothesis shows the value of $-0,388$ and t-statistic amounted to 2.563 on the effect of job satisfaction on turnover intention. The t-statistic value is proven above the t-table value of 1.960 (ttable) and this proves that there is a significant influence between job satisfaction and turnover intention variables. Can be seen through the path coefficient where job satisfaction with turnover intention has a negative influence, so hypothesis 2 can be accepted.

Test results using PLS get generate path coefficients where the value of 0.58 and t-statistics 5.756 on the effect of work stress on intention to leave. The results of this analysis can be seen that the t-statistic values above of 1.960 , and it can be concluded that hypothesis 3 expresses work stress on turnover intention with a positive and significant effect is acceptable.

\section{CONCLUSION}

Based on the results of the analysis of the effect of organizational commitment, job satisfaction and work stress on the turnover intention of outsourcing automotive company employees at PT XYZ, the following conclusions can be drawn:

$>$ From the analysis it can be seen that the level of organizational commitment to turnover intention has a negative influence. From these findings it can be interpreted that employees who have an organizational commitment level that includes affective commitment, ongoing commitment and normative commitment make a significant negative contribution to employee turnover intention which includes the tendency to leave the organization, the possibility of leaving the organization, the possibility of finding other jobs and the existence of more alternative jobs well.
From the results of this analysis job satisfaction with turnover intention has a significant negative effect. This finding can be interpreted as employees who are satisfied with the company which includes: payroll, work, career development and promotion, work groups and supervision as well as colleagues make a significant negative contribution to employee turnover intention. So that employees who are satisfied in working within the company tend to discourage to switch to another company in other words more want to stay in the company.

$>$ Through the analysis results show work stress with turnover intention has a significant positive effect. Through this analysis it can be interpreted that employees who experience work stress through job responsibilities and demands which include being frequently asked to be responsible for work performed by other employees make a significant contribution to increasing employee turnover intention, so employees who feel demands and responsibilities hard work tends to have a high intention to leave or turnover intention in the company.

\section{REFERENCES}

[1]. Andrews, Martha, C., K. Michele Kacmar, Charles Kumar. 2014. The mediational effect of regulatory focus on the relationship between mindfulness and job satisfaction and turnover intention. Career Development International. Vol. 19, No. 5, pp. 494507.

[2]. Aydogdu, Sinem dan Asikgil, Baris. 2011. An Empirical Study of the Relationship Organizational Commitment, and Turnover Intention. International Review of Human Resource, Vol. 1, No.3, pp. 43-53.

[3]. Dhania, Dhini Rama. 2010. Pengaruh Stres Kerja, Beban Kerja terhadap Kepuasan Kerja (Studi pada Medical Representatif di Kota Kudus). Jurnal Psikologi Volume I, No. 1. Universitas Maria Kudus.

[4]. Erry Rimawan, Ali Mustofa, Angga The Influence of Product Quality, Service Quality And Trust On Customer Satisfaction And Its Impact On Customer Loyalty (Case Study PT ABC Tbk).

[5]. Handaru, Agung Wahyu, dan Muna, Lailul. 2012. Pengaruh Kepuasan Gaji dan Komitmen Organisasi terhadap Intensi Turnover pada Divisi PT JAMSOSTEK. Jurnal Riset Manajemen Vol. 3 No. 1. Jakarta: Univers itas Negeri Jakarta.

[6]. Johartono dan Widuri, R. 2014. Analisa Pengaruh Stres kerja, Kepuasan Kerja, Budaya Organisasi dan Komitmen Organisasi Terhadap Turnover intention karywan Kantor Konsultan pajak di Surabaya, Journal of Tax and Accounting Review, Vol. 3, No. 2. Pp. 223-241.

[7]. Mahesa, D. 2010. Analisis Pengaruh Motivasi dan Kepuasan Kerja terhadap Kinerja Karyawan dengan Lama Kerja Sebagai Variabel Moderating (Studi pada PT Coca Cola Amatil Indonesia (Central Java). Jawa Tengah. 
[8]. Rini, Nindya Setyo. 2018. Pengaruh Beban Kerja terhadap Kepuasan Kerja dengan Stress Kerja sebagai Variabel Mediasi pada PT. Malang Post Cemerlang, Kota Malang. Skripsi. Universitas Muhammadiyah Malang.

[9]. Syahronica, Gabriela. 2015. Pengaruh Kepuasan Kerja dan Stres kerja terhadap Turnover Intention. Studi pada karyawan departemen dunia fantasi PT. pembangunan jaya ancol Tbk. Jurnal Administrasi Bisnis. Vol. 20, No. 1, pp. 1-6.

[10]. Wulandari, Astri. 2011. Pengaruh Employer Brand Terhadap Intensi Voluntary Turnover Karyawan dengan Mediasi dari Komitmen Organisasi dan kepuasan Kerja Studi Kasus: PT. Asuransi Jiwa XYZ. Jurnal Manajemen Fakultas Ekonomi Universitas Indonesia. Vol. 3, No. 9. Pp. 227-235. 